\title{
Evidence-based policy making? The case of Polish opposition to the EU Tobacco Products Directive
}

\author{
Mateusz Zatoński \\ London School of Hygiene and Tropical Medicine, London, United Kingdom
}

\begin{abstract}
In December 2012 the European Union (EU) Commission announced that it will propose a revision of the 2001 Tobacco Products Directive (TPD). This paper traces the policy debate that followed, in order to highlight some of the intricacies of the research-policy nexus. It focuses on the voting decisions of the Polish Members of the European Parliament (MEPs) during the European Parliament vote on the TPD in October 2013. The presented analysis employs a variety of theoretical models, including the engineering, enlightenment and strategic models of evidence-based policy making, the "two communities" model, framing, as well as Black's list of reasons for why research evidence has little influence on service policies. The analysis demonstrates that a linear model of relation between research and policy is of little value in understanding the EU TPD voting outcomes due to the broad and strongly antagonistic nature of the advocacy coalitions competing to influence the political decisions of the MEPs on this issue.
\end{abstract}

KEY WORDS: research-policy nexus, tobacco products directive, European Union, policymaking, Poland.

ADDRESS FOR CORRESPONDENCE: Mateusz Zatoński, London School of Hygiene and Tropical Medicine, Keppel Street, London WC1E 7HT, United Kingdom, phone: +44 7415240 171, e-mail: mateusz.zatonski@lshtm.ac.uk

\section{INTRODUCTION}

Carl Sagan reputedly wrote that "if we did not respect the evidence, we would have very little leverage in our quest for the truth". Most of the participants of the debate on the shape of the Revision to the European Union (EU) Tobacco Products Directive (TPD) would concur with Sagan's sentiment. And yet the fierce dispute that followed the EU Commission's announcement in December 2012 that it will propose a revision of the 2001 Tobacco Products Directive suggests, that even if all the involved parties accepted the importance of research in policymaking, they might have been looking at different sets of evidence.

This paper traces the policy debate that followed the EU Commission's announcement, in order to highlight some of the intricacies of the research-policy nexus. Due to the complex and multi-level nature of policymaking in supranational institutions such as the EU it predominantly focuses on the way research impacted voting decisions of Polish Members of European Parliament (MEPs) during the European Parliament vote on the TPD in October 2013. The principal conceptual framework used to inform the analysis has been adapted from Black's list of reasons for why research evidence has little influence on service policies [1]. This is supplemented by theoretical insights from the "engineering", as well as "enlightenment" and "strategic" models of evidence-based policy [2], as well as literature on the "two communities" model [3], and on the importance of framing [4]. The resulting analysis will demonstrate that a linear model of relation between research and policy is of little value in understanding the EU TPD debate due to the broad and strongly antagonistic nature of the advocacy coalitions competing to influence the political decisions of the Europarlamentarians on this issue.

\section{POLICY BACKGROUND}

The original EU TPD from 2001 laid out progressive laws regulating the manufacture, marketing and sale of tobacco products in Europe. This included limits for tar, 
nicotine and carbon monoxide in cigarettes, required health warnings on tobacco packaging, and a ban on descriptions such as "light". The regulation was hailed by the EU officials as being in line with research on minimising tobacco harm and representing the linear approach to policy development whereby scientific evidence translates directly to legislation [5]. This could be disputed as the so-called "engineering model" requires there to be a "relatively rapid relationship between research findings and policy decisions" [6]. Meanwhile, the evidence of extensive harm of smoking, second-hand smoking, as well as the positive influence regulating the tobacco market will have on decreasing smoking prevalence, existed since many years before the TPD was implemented. In addition, the different EU countries had pre-existing tobacco regulation, while under the "engineering" model research precedes policy solution [1]. The European policymakers in 2001 thus had to not only take under account the existing research, but also to harmonise the legislation of the EU's numerous member states. It could be thus argued that the policymaking behind the original TPD represented more closely Weiss' "enlightenment model", whereby research exerts a gradual, cumulative effect on policy, and it can take a long time before the resulting legislation [2].

In 2011 the EU Commission undertook a summative evaluation of the original TPD. According to Buse et al., the purpose of such evaluations is to "provide a verdict on a policy or programme" [6], and they could be seen as the beginning of a new policymaking cycle leading to updated legislation. The Commission deemed that "market, scientific and international developments" that have occurred since the original TPD warrant a revision of the directive [5]. Among the key proposals of the Revision was introducing mandatory pictorial warnings of $75 \%$ on top of cigarette packs, the ban on the sale of "slim" cigarettes and adding flavouring to cigarettes, as well as a host of other provisions such as minimum numbers of cigarettes to be sold in a pack or increasing the traceability of tobacco products to prevent smuggling [7]. These revisions were then passed on to a vote in the European Parliament that took place in October 2013.

Poland, the most populous country to have entered the EU in the last few rounds of accession, with 51 MEPs, had the sixth highest number of Europarlamentarians out of the EU member states. Since it was predicted that the vote on the provisions of the updated TPD might be very close, their role was crucial in deciding on its outcome. This proved to be true. The vast majority of MEPs voted along the lines of EU political parties - with the Left and Greens voting predominantly for the more strict regulation of tobacco products, while the Liberals and Right voting for softening the proposed Revision in favour of the industry. The only one exception to this rule were the Polish MEPs who, regardless of their political affiliation, voted for smaller sizes of pictorial warnings, less regulation of tobacco sales, and no ban on "slim" or menthol cigarettes [8]. As a result the European Parliament decided to reduce the size of pictorial warnings to $65 \%$ of the pack, not ban the sale of "slims", and permit an eight year transition period before implementing the ban on menthol flavouring [7].

How did the decision of the Polish MEPs fit into the research-policy nexus? Did they simply disregard the evidence at their disposal? Using Nicholas Black's model from 2001 can help us understand the reasons underpinning their decision, and recognise that the impact of evidence was not quite discounted from their decision-making process. While Black used his list to explain the dynamics of policymaking in health service policies, elements of it can be adapted and used to understand the voting outcome of the TPD debate. What is particularly pertinent to this case study are Black's assertions that:

- there may be a lack of consensus about research evidence,

- policy makers have goals other than clinical effectiveness (or, in this case, positive health outcomes). Social environment might not be conducive to policy change.

\section{LACK OF CONSENSUS OVER EVIDENCE}

The first factor that influenced the decision to vote against stricter regulation of tobacco products taken by the Polish MEPs was the fact that the anti-tobacco evidence was complex and subject to various interpretations. Health advocates, including the WHO, the EU Commission, health researchers, and anti-tobacco advocates organised in a variety of organisations, argued that larger health warnings or banning certain tobacco flavouring, will have palpable positive effect on the health of Europeans by helping decrease smoking prevalence and initiation. However, in the words of Macintyre et al., for changes aiming to modify tobacco consumption "randomised experimental evidence is never likely to be available" [9]. Natural experiments from around the world were cited by the proponents of stricter regulation, but these were limited and criticised as not easily translatable to the European context. Making twenty the minimum number of cigarettes in a pack was countered by various "commonsensical" arguments claiming that people will just buy more packets. Similarly, the arguments over the ban on menthols, based on the evidence that they reduce throat irritation and facilitate initiation [7], were dismissed by the Polish media as a minor issue - the public opinion struggled to understand why flavoured tobacco products in particular should be banned [10]. The health advocates also failed to link the most resounding argument, that tobacco use and exposure to second-hand smoke claim well over 700,000 lives in the EU every year, with the particular policies proposed in the TPD Revision. 
Peter Taylor wrote in his 1984 book The Smoke Ring [11] that smoking "is frequently seen only as a matter of industry 'villains' versus public health 'heroes'”. In 2013 the situation was quite different. Health advocates did not have a monopoly on supplying Europarlamentarians with research evidence. Opponents of strict provisions contained in the TPD Revision were effective in providing competing evidence that was seen as credible by the policymakers. They were endorsed by European tobacco farmers, Ministries of Economy of many EU countries including Poland, various organisations coalescing small businesses, and of course the powerful tobacco industry. They proposed evidence suggesting that the TPD Revision will have a negligible health impact, criticised the restrictions on "harm reduction" products such as smokeless tobacco, and emphasised the economic toll the changes would have on Europe. Their arguments were promptly picked up by the Polish media [12].

The pro-tobacco camp was much more effective at communicating its evidence, particularly to the Polish MEPs. They emphasised the huge revenue Poland gains from taxing tobacco, the amounts of jobs that will be lost if the TPD Revision is implemented in an unchanged form, the rise of cigarette smuggling, and the role of Poland as the biggest manufacturer of flavoured cigarettes and menthols in the EU [13]. Unlike their opponents, they did not take the position of "high priests of medical research" who expect their evidence to be unquestioningly accepted [14]. Instead, they made sure the evidence they used would be heard and reiterated by associations of Polish farmers, shopkeepers, and other groups with political leverage. The pro-tobacco camp was better at disseminating and communicating its evidence, but it also had the means to do so - according to McKee Philip Morris spent over $£ 1 \mathrm{~m}$ in 2012 on lobbying MEPs [7]. Finally, it had the advantage of postulating the maintenance of status quo, which is generally favoured by the policymakers to research that suggests radical change [6].

\section{GOALS OF POLICYMAKERS AND THE EXISTING SOCIAL ENVIRONMENT}

On the surface, the TPD Revision provided a wideopen window of opportunity for the implementation of research-based evidence into policy. The Revision itself was proposed by the EU Commission and the Lithuanian government which held the Presidency of the EU in the second half of 2013, and which was a strong supporter of the Revision [15]. However, claiming that the political context in 2013 was conducive to the acceptance of this policy proposal would be forgetting the spectre of the ongoing economic crisis in Europe. While during the formulation of the original TPD health arguments were paramount, a decade later research on economic outcomes of the Revision were listened to much more attentively, even by those stakeholders whose main responsibility was theoretically health. This was demonstrated most strikingly by the Polish Health Minister Bartosz Arłukowicz, who, in June 2013, declared that the Polish MEPs should reject the TPD Revision as its economic consequences could lead to rising levels of euroscepticism in Poland [16]. Political decision-makers sometimes choose to overlook health-related evidence in order to accommodate other legitimate influences on policy that appear more significant in this particular context [1]. This was how the Polish MEPs behaved in regards to the TPD Revision in view of the financial crisis and economic importance of the tobacco growing and manufacturing industry in Poland [17].

Frames "shape [...] what counts as a good or bad outcome of our actions" [4]. In the previous policymaking cycles European health advocates were successful in imposing their framing of the discussion as one over lives saved or passive smoking [18]. This was not the case this time. Successfully framing the debate over the TPD as one over "costs" was an important element of the pro-tobacco lobbyists' success in making the evidence that supported their case more resonant with the Polish MEPs. The economic costs of smoking were compared with the economic costs of a reduction in sale and manufacture of tobacco products in Poland. The health advocates tried to stand their ground, for example by questioning the high estimates the tobacco industry provided on how much smuggling costs will increase after the TPD Revision is accepted [19]. However, disagreement on how much they should engage the tobacco industry on economic grounds was rife, and they failed to present a united front, with some arguing that certain provisions of the TPD Revision, such as the regulation of e-cigarettes, could be sacrificed. Meanwhile the pro-tobacco researchers and advocates overcame any differences between them forming a tighter policy community by simply rejecting all the proposals of the TPD Revision, which allowed them to present their evidence in a more cohesive and forceful manner [20,21]. The evidence-based message that reached the policymakers was therefore that the negative economic impact of the TPD will be burdensome on the Polish economy rendered fragile by the financial crisis, and that the declining economic costs of smoking will not be able to make up for this loss [10].

As with most policy decisions, policymakers faced trade-offs - in this case between health and financial considerations - and they made a political choice based on the value that they saw as dominant in society at the time [22]. The Polish MEPs, facing strong pressure from the media and business lobbies, followed a pattern best described by Weiss as the "strategic model", where they used the research as "ammunition to support predetermined positions" [2]. Citing economic evidence, they voted for weakening the TPD Revision. 


\section{CONCLUSIONS}

The case study of the TPD Revision did not follow the pattern outlined by the "two communities" model [6]. Rather than researchers and policymakers living in different cultures what could be observed was a conflict among two coalitions which included researchers, policymakers, as well as journalists - this pattern conformed to Gibson's criticism of the "two communities" model [3]. Policymakers therefore did base their decision on a fundament of evidence, albeit one that they chose strategically. The resulting dynamic might better be understood using the Advocacy Coalition Framework proposed by Sabatier and Jenkins-Smith, whereby the key to understand policymaking are policy subsystems consisting of a mixture of actors sharing basic values and problem perceptions "who play important roles in the generation, dissemination, and evaluation of policy ideas" [23].

\section{DISCLOSURE}

Author reports no conflict of interest.

\section{References}

1. Black N. Evidence based policy: proceed with care. BMJ 2001; 323: $275-278$

2. Weiss $\mathrm{CH}$. The many meanings of research utilization. Public Administration Review 1979; 39: 426-431.

3. Gibson B. Beyond "two communities". In: Evidence-based health policy: problems \& possibilities. Lin V, Gibson B (eds.). Oxford University Press, Oxford 2003.

4. Lakoff G. Don't think of an elephant: know your values and frame the debate. White River Junction, VT, Chelsea Green Publishing 2004.

5. Tobacco Products. European Commission, 2013. Available from http://ec.europa.eu/health/tobacco/products/index_en.htm; (accessed: 15 December 2013).

6. Buse K, Mays N, Walt G (eds.). Making Health Policy. Open University Press, London 2012

7. McKee M. European Union Tobacco Products Directive. Br Med J 2013; 347: f6196.

8. Vote Watch Europe. Available from: http://www.votewatch.eu/ (accessed: 20 November 2013).

9. Macintyre S, Chambers I, Horton R, et al. Using evidence to inform health policy: case study. BMJ 2001; 322: 222-225.

10. Zakaz slimów i mentoli zlikwiduje tysiące miejsc pracy w Polsce. [The ban on slims and menthols will take away thousands of jobs in Poland]. Forbes Polska, 2013. Available from: http://www.forbes.pl/zakaz-slimow-i-mentoli-zlikwiduje-tysiace-miejsc-pracy-w-polsce,artykuly,161449,1,1.html (accessed: 3 December 2013).

11. Taylor P. Smoke Ring. The Politics of Tobacco. The Bodley Head, London 1984.

12. Ross G. The EU's New Tobacco Directive: Protecting Cigarette Markets, Killing Smokers. Available from: http://www.forbes. $\mathrm{com} /$ sites/realspin/2013/01/10/the-eus-new-tobacco-directiveprotecting-cigarette-markets-killing-smokers/ (accessed: 13 December 2013).
13. Wyborcza.biz. Polska przeciw dyrektywie zakazującej papierosów mentolowych. [Poland opposes the directive banning menthol cigarettes]. Available from: http://wyborcza.biz/biznes/ 1,100896,13293460,Polska_przeciw_dyrektywie_zakazujacej_ papierosow_mentolowych_html (accessed: 29 November 2013).

14. Kuruvilla S, Mays N. Reorienting health-research communication. Lancet 2005; 366: 1416-1418.

15. Lithuanian Presidency of the Council of the European Union. Lithuanian Presidency successfully concluded negotiations on Tobacco products directive. Available from: http://www.eu2013. lt/en/news/pressreleases/lithuanian-presidency-successfullyconcluded-negotiations-on-tobacco-products-directive (accessed: 18 December 2013).

16. Rynek Zdrowia. Spór o dyrektywę tytoniową. [The struggle over the tobacco directive]. Available from: http://www.rynekzdrowia.pl/Polityka-zdrowotna/UE-spor-o-dyrektywe-tytoniowa-Arlukowicz-krytykuje-zakaz-mentolu-pochwala-obrazki,131629,14.html (accessed: 14 December 2013).

17. Zatoński W, Zatoński M, Przewoźniak K. Health improvement in Poland is contingent on continued extensive tobacco control measures. Ann Agric Environ Med 2013; 20: 405-411.

18. Berridge V, Stanton J. Science and policy: historical insights. Soc Sci Med 1999; 49: 1133-1138.

19. Stokłosa M, Ross H. Contrasting academic and tobacco industry estimates of illicit cigarette trade: evidence from Warsaw, Poland. Tob Control 2014; 23(e1): e30-e40.

20. Davies H, Nutley S, Smith P. Introducing evidence-based policy and practice in public services. In: What works? Davies $\mathrm{H}$, Nutley SM, Smith PC (eds.). The Policy Press, Bristol 2000.

21. Nutley S, Webb J. Evidence and the policy process. In: What works? Davies H, Nutley SM, Smith PC (eds.). The Policy Press, Bristol 2000.

22. Parkhurst J. Evidence Based Policy sounds great, doesn't it? Available from: http://socialscienceandhealth.blogspot.co.uk/ (accessed: 29 November 2013).

23. Sabatier PA. Policy change over a decade or more. Policy Change and Learning. In: An Advocacy Coalition Approach. Sabatier PA, Jenkins-Smith HC (eds.). Westview Press, Boulder 1993. 